\title{
Land capability and irrigability classification of soils of Thotapalli major irrigation project of North Coastal Andhra Pradesh
}

K. Himabindu and P. Gurumurthy

Received : 04.09.2018; Revised : 08.11.2018; Accepted : 17.11.2018

\section{MEMBERS OF RESEARCH FORUM:}

Corresponding author : P. Gurumurthy, Department of Soil Science and Agricultural Chemistry, Agricultural College (A.N.G.R.A.U.), Naira, Srikakulam (A.P.) India

Email: peddintigurumurthy@gmail. com

\section{Co-authors :}

K. Himabindu, Department of Soil Science and Agricultural Chemistry, Agricultural College (A.N.G.R.A.U.), Naira, Srikakulam (A.P.) India

\section{Summary}

A study was conducted to assess land capability and irrigability classification of soils under Thotapalli major irrigation project of North Coastal Andhra Pradesh. Horizon wise soil samples from six representative soil pedons located at Devarapalli, Gujjangivalasa, Patikivalasa, Gangada, Aamiti and Maddivalasa villages were studied. The red and associated soils of upland soils were gently sloping while black soils were nearly level cultivated plains. In general the texture ranged from loamy sand to clay, moderately deep to deep, slight to moderate erosion, nil to slight flooding, good to poor drainage. In respect of fertility status the soils in general were low to medium in organic carbon, the CEC values ranged from 6.4 to $32.5 \mathrm{cmol}$ $(\mathrm{p}+) \mathrm{kg}^{-1}$ and base saturation was 23 to 88 per cent. Free calcium carbonate was found in pedons 3, 4 and 6. The ESP was low, EC was non saline (less than $4.0 \mathrm{dSm}^{-1}$ ). The climate of study area was characterised by sub-humid with distinct wet and dry seasons. These soils fall under land capability classes of II, III and IV with distinct limitations. The land irrigability classes of these soils were identified as S1, S2 and S3 with distinct limitations.

Key words : Soil characterization, Soil physical propertiesn, Soil chemical properties, Land capability classification, Land irrigability classification, Wetness, Erosion

How to cite this article : Himabindu, K. and Gurumurthy, P. (2018). Land capability and irrigability classification of soils of Thotapalli major irrigation project of North Coastal Andhra Pradesh. Asian J. Soil Sci., 13 (2) : 120-125 : DOI : 10.15740/HAS/AJSS/13.2/120-125. 